\title{
ANALISIS PENGARUH KEBIJAKAN MONETER TERHADAP RETURN INDEKS SAHAM INFOBANK15 DI INDONESIA PERIODE NOVEMBER 2012- FEBRUARI 2016 (STUDY KASUS PADA INDEKS SAHAM PERBANKAN INFOBANK15 YANG TERDAFTAR DI BURSA EFEK INDONESIA)
}

\author{
Eva Yudika Sembiring \\ Fakultas Ekonomi dan Bisnis Universitas Brawijaya \\ Email: evayudika@ymail.com \\ Al Muizzuddin Fazaalloh \\ Fakultas Ekonomi dan Bisnis Universitas Brawijaya \\ Email: almuiz.wang@ub.ac.id
}

\begin{abstract}
This study was aimed to see the effects of of monetary policy on Infobank15 index return listed on the Indonesia Stock Exchange. Monetary policy variables is proxied through BI rate, followed by inflation and exchange rate, as well as the Dow Jones index as a control variable. The method of data analysis was multiple regression analysis using secondary data from November 2012 to February 2016. The results showed that the BI rate, inflation, exchange rate, and the Dow Jones index significantly take effect to on Infobank15 index return. The coefficient of determination equals to 0.73 which means that $73 \%$ of Infobank15 index returns can be explained by BI Rate, Inflation, exchange rate, and the Dow Jones Index while the rest (27\%) is explained by other variables outside of the regression model..
\end{abstract}

Keywords: Monetary Policy, Infobank15 index return, BI Rate, multiple regression.

\section{PENDAHULUAN}

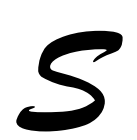

tabilitas sistem perbankan dan sistem kebijakan moneter merupakan dua aspek penting yang saling berkaitan dengan erat. Stabilitas sistem perbankan dapat dilihat dari fungsi intermediasinya dalam memobilisasi dana yang dihimpun dan yang disalurkan kepada masyarakat. Sedangkan untuk stabilitas kebijakan moneter dapat dilihat melalui stabilnya harga yang tercermin dari inflasi yang rendah. Indonesia merupakan salah satu Negara yang memiliki pasar

QE Journal | Vol.06 - No. 01 Maret 2017 - 16 
keuangan yang cukup berkembang, termasuk pasar saham. Pasar saham ini merupakan suatu kebutuhan untuk perkembangan ekonomi karena aliran modal melalui pasar saham ini dapat digunakan untuk pendanaan pembangunan ekonomi.

Dalam perkembangannya, Pasar Modal memiliki peran yang sangat penting bagi perekonomian suatu Negara karena pasar modal mempunyai dua fungsi utama dalam menjalankan perekonomian. Yang pertama sebagai sarana pendanaan usaha bagi perusahaan untuk mendapatkan dana dari investor. Dengan demikian dana yang diperoleh dari pasar modal dapat digunakan dalam pengembangan usaha, penambah modal kerja, ekspansi, dan lain-lain. Untuk fungsi yang kedua pasar modal merupakan sarana bagi masyarakat untuk berinvestasi pada instrumen keuangan seperti saham, obligasi, reksadana, dan lain-lain.

Untuk meningkatkan efektivitas pemantauan tersebut dibutuhkan suatu pengawasan yang lebih intensif atas beberapa indikator yang dapat mempengaruhi stabilitas perbankan dan sektor keuangan. Perkembangan pasar modal merupakan suatu indikator penting yang dipantau. Pemantauan dilakukan terhadap pasar modal karena merupakan bagian dari sistem keuangan dan perbankan juga merupakan emiten dalam investasi di pasar modal. Secara spesifik kebijakan moneter dapat mempengaruhi harga saham melalui beberapa cara, salah satunya melalui melalui tingkat suku bunga.

Peningkatan tingkat suku bunga yang tercermin dari inflasi yang tinggi dapat menurunkan nilai aliran present value dari pendapatan return saham dan menekan pasar modal (Tobin, 1969). Ketika tingkat suku bunga tinggi maka masyarakat enggan untuk berinvestasi di pasar modal, mereka lebih memilih untuk berinvestasi di obligasi karena lebih menarik dan dianggap lebih aman dibandingkan dengan saham. Kedua, harga dan return saham secara kumulatif berdampak terhadap konsumsi individu dan investasi individu karena kondisi makroekonomi yang dapat mempengaruhi pendapatan dan kekayaan seseorang ( Bernanke dan Kuttner, 2005). Ketiga, karena saham dipandang sebagai investasi yang relatif berisiko, investor umumnya meminta kualitas saham premium untuk memegang saham.

Oleh karena itu, hasil yang diharapkan pada saham ceteris paribus dapat naik hanya melalui penurunan harga saham saat ini (Bernanke, 2003). 
BI rate merupakan salah satu proxy yang digunakan dalam kebijakan moneter karena BI rate merupakan stance kebijakan moneter yang dapat mempengaruhi seluruh sektor perekonomian melalui transmisinya (Prastowo,2008). Beberapa penelitian telah dilakukan terhadap kinerja saham perbankan, salah satunya yaitu penelitian yang dilakukan oleh Edwin Prabu dkk (2015) yang menyatakan bahwa secara statistik kebijakan moneter tidak berpengaruh signifikan terhadap kinerja saham, meskipun terdapat beberapa peristiwa yang dapat mengejutkan pasar, seperti kebijakan pengetatan moneter yang dapat menurunkan return saham khususnya saham sektor perbankan. Berbeda dengan penelitian yang dilakukan oleh Güray Küçükkocaoğlu dkk (2011) menyatakan bahwa return saham bank secara umum merespon keadaan moneter secara signifikan, namun kurang signifikan jikan dibandingkan dengan bank asing. Lalu penelitian yang dilakukan oleh Ovidiu Stoica dkk dengan menggunakan metode VAR menyatakan bahwa kebijakan moneter berpengaruh signifikan terhadap saham pada negara berkembang.

Selanjutnya penelitian yang dilakukan oleh Christos Ioannidis dkk (2006) menyatakan bahwa kebijakan moneter berpengaruh signifikan terhadap return saham. Rowland \& Mikail (2013) menyatakan bahwa inflasi berpengaruh negative terhadap return saham. Hal ini disebabkan Ketika inflasi tinggi, kecenderungan perekonomian sedang mengalami resesi sehingga mengurangi keuntungan perusahaan. Penurunan expected return akan menyebabkan saham kurang diminati karena adanya portofolio switching, yaitu pengalihan investasi dari saham ke investasi bebas risiko. Umumnya sektor yang paling terkena dampak dari adanya peningkatan inflasi adalah sektor perbankan, otomotif, property, konsumsi dan ritel (Wira, 2014).

Hubungan antara kurs dengan kinerja saham merupakan suatu teori yang menjelaskan tentang model flow oriented (Dombusch dan Fisher, 1980). Teori ini menyatakan bahwa pergerakan kurs akan mempengaruhi tingkat persaingan kompetitif perusahaan dan mempengaruhi neraca perdagangan, dan hal ini akan berdampak terhadap output riil suatu negara, dimana hal ini akan berpengaruh terhadap aliran kas (cash flow) perusahaan dan kinerja saham mereka. Selain itu Zohain dkk (2012) menyatakan bahwa kurs berpengaruh negative terhadap return saham. Hal ini disebabkan adanya investor asing yang mengkonversikan hasil return

QE Journal | Vol.06 - No. 01 Maret 2017 - 18 
investasi mereka kedalam mata uang negaranya sehingga semakin tinggi kurs maka capital outflow akan semakin tinggi karena keinginan mereka untuk berinvestasi menjadi rendah sehingga return saham akan turun. Rovčanin, Abdić, \& Abdić (2015) menyatakan bahwa indeks bursa asing turut mempengaruhi pasar modal domestic. Hal ini disebabkan oleh kondisi global yang juga mempengaruhi dan mengubah struktur kapitalisasi yang ada di lantai bursa, termasuk Indonesia. Dengan adanya investor asing dalam pasar modal, maka terdapat hubungan antara satu bursa dengan bursa lainnya, sehingga saat satu bursa saham mengalami penurunan maka investor akan mengalihkan modalnya pada bursa yang sedang mengalami peningkatan trend.

Teori fenomenal yang sering dijadikan sebagai rujukan dalam melihat pengaruh kebijakan moneter terhadap pasar modal adalah Teori Tobin. Teori ini menjelaskan bagaimana kebijakan moneter dapat mempengaruhi ekonomi secara riil melalui harga saham di pasar modal. Teori Tobin merupakan salah satu teori yang digunakan sebagai salah satu rujukan dalam melihat pengaruh kebijakan moneter terhadap pasar saham (Ehrmann \& Fratzscher, 2004) karena sifat endogenitas kebijakan moneter sehingga masih sulit untuk untuk membuktikan pengaruh kebijakan moneter terhadap pasar saham secara akurat. Menurut Tobin, terdapat dua jalur mekanisme transmisi kebijakan moneter yang mempunyai dampak penting terhadap harga saham, dimana teori ini disebut teori Tobin yaitu teori investasi dan efek kekayaan terhadap konsumsi (Tobin's q). Teori Tobin q menggambarkan framework dan mekanisme dimana kebijakan moneter dapat mempengaruhi perekonomian melalui penilaiannya terhadap saham. Nilai q menggambarkan nilai pasar suatu perusahaan terhadap biaya pengganti modal. Nilai Tobin q diukur dalam skala rasio dari nilai pasar suatu perusahaan terhadap biaya pengganti modal perusahaan, adapun bentuknya adalah sebagai berikut.

$$
\text { Tobin' } Q=\frac{\text { Market value of firm }}{\text { Replacement cost of capital }}
$$

Ketika nilai q tinggi, maka harga pasar suatu perusahaan secara relative juga tinggi dibandingkan dengan nilai pengganti modalnya, maka harga menjadi murah untuk memperoleh bangunan dan peralatan dibandingkan harga pasar dari suatu perusahaan. Perusahaan juga dapat menerbitkan modal baru dan memperolah harga tinggi untuk biaya yang telah dipakai

QE Journal | Vol.06 - No. 01 Maret 2017 - 19 
dalam membeli peralatan ataupun biaya lainnya yang telah dipakai. Pengeluaran investasi akan semakin tinggi karena perusahaan mampu mendapatkan banyak barang-barang investasi baru dengan modal yang cukup kecil dari menerbitkan suatu saham. Sebaliknya, investasi akan rendah jika nilai q juga rendah, sehingga pengeluaran investasi dalam perekonomian juga akan menurun.

Teori lain juga dikembangkan oleh Ioannidis dan Kontonikas (2008) yang menyatakan bahwa nilai present value atau model discounted cash flow memberikan gambaran mengenai dampak perubahan kebijakan moneter terhadap pasar modal. Dikatakan bahwa perubahan kebijakan moneter dapat mempengaruhi return saham melalui dua cara, pertama yaitu dampak langsung return saham melalui tingkat suku bunga (discount rate), kenaikan suku bunga menyebabkan return saham perusahaan turun. Kedua, perubahan kebijakan moneter menggunakan pengaruh tidak langsung terhadap nilai saham perusahaan dengan mengubah expected future cash flow nya.

\section{METODE PENELITIAN}

Ruang lingkup penelitian yang digunakan dalam penelitian ini adalah indeks saham perbankan yang terdaftar di Bursa Efek Indonesia (BEI). Jenis data yang digunakan merupakan data sekunder dengan pendekatan kuantitatif, yaitu data yang diolah melalui data-data yang telah dipublikasikan oleh media tertentu dan studi pustaka. Data yang digunakan dalam penelitian ini adalah time series bulanan mulai November 2012 hingga Februari 2016. Sumber data berasal dari web resmi Bank Indonesia, yaitu www.bi.go.id, yahoo finance dan web resmi Bursa Efek Indonesia, yaitu www.idx.co.id serta instansi-instansi terkait lainnya. Populasi yang digunakan dalam penelitian ini adalah seluruh saham yang terdaftar di pasar modal Bursa Efek Indonesia (BEI) yang telah dirangkum oleh BEI melalui laporan publikasi Statistik Pasar Modal Indonesia dengan sampel penelitian indeks saham perbankan Infobank15 yang terdaftar dalam pasar modal Bursa Efek Indonesia.

Adapun variabel penelitian yang digunakan terdiri dari variabel dependent dan variabel independen. Variabel terikat ( $Y$, dependent variable) yang digunakan dalam penelitian ini adalah return indeks Infobank15, 
sedangkan variabel bebas $(X$, independent variable) yang digunakan yaitu BI Rate, inflasi, kurs, dan indeks dow jones.

Metode analisis data yang digunakan dalam penelitian ini adalah metode analisis regresi linear berganda dengan melakukan uji asumsi klasik dan uji hipotesis. Analisis ini digunakan dengan bantuan software Eviews 9. Tujuan dari analisis ini adalah untuk melihat bagaimana pengaruh variabel bebas terhadap variabel terikat. Adapun model regresi yang digunakan yaitu

$$
Y=\beta_{0}+\beta_{1} X_{1}+\beta_{2} X_{2}+\beta_{3} X_{3}+\beta_{4} X_{4}+\varepsilon
$$

Dimana:

$\mathrm{Y}$ : return indeks Infobank15

$\beta_{0}$ : konstanta/ intersep

$\mathrm{x} 1$ : Kurs

x: Inflasi

x3: BI Rate

$\mathrm{x}_{4}$ : Indeks Dow Jones

$\beta_{1,2,3,4}$ : Koefisien/slope masing-masing variabel bebas

$\varepsilon$ : error term

\section{HASIL DAN PEMBAHASAN}

Hasil Analisis Data

Dengan menggunakan metode Ordinary Least Square (OLS) maka hasil regresi yang diperoleh dapat dilihat melalui table 1 dibawah ini.

Tabel 1. Hasil Regresi

\begin{tabular}{lll}
\hline $\begin{array}{l}\text { Dependent variable } \\
\text { Variabel }\end{array}$ & $\begin{array}{l}\text { Y (Return } \text { Infobank15) } \\
\text { Coefficient }\end{array}$ & Prob. \\
\hline BI Rate (X1) & 15.09291 & 0.0039 \\
Inflasi (X2) & -3.812302 & 0.0010 \\
Kurs (X3) & -0.016044 & 0.0000 \\
Dow Jones (X4) & 0.007039 & 0.0033 \\
C & 4.160576 & 0.8163 \\
R-squared & 0.695242 & \\
Prob (F-Stat) & 0.0000 & \\
Durbin-Watson stat & 1.468262 & \\
\hline
\end{tabular}

Sumber: Eviews 9, diolah

QE Journal | Vol.06 - No. 01 Maret 2017 - 21 
Berdasarkan model regresi diatas maka dilakukan uji asumsi klasik untuk melihat apakah model regresi pada table diatas dapat digunakan sebagai model acuan dalam penelitian ini.

Hasil Uji Normalitas

Tabel 2. Hasil Uji Normalitas

\begin{tabular}{ll}
\hline Nama Uji & Histogram Normality Test \\
\hline probability & 0.230107 \\
alpha & 0.05 \\
\hline
\end{tabular}

Sumber: Eviews 9, data diolah

Berdasarkan tabel 2 diatas, nilai probabilitas sebesar 02 dimana nilai ini lebih besar dari alpha 5\% (0.05) sehingga dapat disimpulkan bahwa nilai residual telah terdistribusi secara normal.

Hasil Uji Heterokedastisitas

Tabel 3. Hasil Uji Heterokedastisitas Glejser Test

\begin{tabular}{llll}
\hline F-Statistic & 1.73 & Prob.F(4,35) & 0.16 \\
\hline Obs*R-squared & 6.61 & Prob.Chi-square(4) & 0.15 \\
Scaled explained SS & 5.17 & Prob.Chi-square (4) & 0.27 \\
& & & \\
\hline
\end{tabular}

Sumber: Eviews 9, data diolah

Berdasarkan hasil diatas diperoleh nilai $\mathrm{Obs}^{*} \mathrm{R}$-squared sebesar 6.61 sedangkan nilai probabilitas (chi-square) adalah 0.15 , lebih besar dari $\alpha=5 \%$. Dengan demikian kita dapat menerima hipotesis $\mathrm{H}_{0}$ sehingga data penelitian bebas dari gejala heterokedastisitas.

Hasil Uji Multikolinearitas

Tabel 4. Hasil Uji Multikolinearitas

\begin{tabular}{lll}
\hline Variabel & VIF & Keterangan \\
\hline BI Rate (X1) & 5.76 & Tidak terdapat gejala Multikolinearitas \\
Inflasi (X2) & 1.28 & Tidak terdapat gejala Multikolinearitas \\
Kurs (X3) & 3.53 & Tidak terdapat gejala Multikolinearitas \\
DJ (X4) & 4.55 & Tidak terdapat gejala Multikolinearitas \\
\hline
\end{tabular}

Sumber: Eviews 9, data diolah

QE Journal | Vol.06 - No. 01 Maret 2017 - 22 
Berdasarkan hasil estimasi diatas diperoleh nilai VIF untuk setiap variabel, yaitu BI Rate $(X 1)=5.76$, Inflasi $(X 2)=1.28$, Kurs $(X 3)=3.53$, dan DJ $(X 4)=$ 4.55, masing-masing kurang dari 10, sehingga dapat dikatakan data tersebut bebas dari gejala multikolinearitas.

Hasil Uji Autokorelasi

Tabel 5. Hasil Uji Autokorelasi

\begin{tabular}{ll}
\hline R-squared & 0.695242 \\
\hline Prob (F-Stat) & 0.0000 \\
Durbin-Watson stat & 1.468262 \\
\hline
\end{tabular}

Sumber: Eviews 9, data diolah

Berdasarkan hasil analisis regresi diperoleh nilai durbin watson $(\mathrm{dw})$ sebesar 1.46 dengan nilai $\mathrm{dL}=1.29$ dan $\mathrm{dU}=1.72$, sehingga $\mathrm{dL} \leq \mathrm{DW} \leq \mathrm{dU}$ dan hasil tidak dapat disimpulkan. Oleh karena itu perlu dilakukan suatu cara unuk mengobati autokorelasi tersebut. Salah satu cara yang dapat digunakan yaitu dengan metode Cochrane-Orcutt (C-O). Metode ini dilakukan dengan melihat koefisien autokorelasi lalu dilanjutkan dengan transformasi data. Kemudian dari hasil transformasi dilakukan pendeteksian ulang untuk mendeteksi ada tidaknya autokorelasi. Jika pada data hasil transformasi masih terdapat gejala autokorelasi, maka dilakukan transformasi ulang sampai tidak ada autokorelasi.

Tabel 6. Hasil Regresi setelah diperbaiki dengan Cochrane-Orcutt (C-O)

\begin{tabular}{lll}
\hline dependent variable & Y (Return Infobank15) & \\
\hline Variabel & Coefficient & Prob. \\
BI Rate (X1) & 15.09291 & 0.0039 \\
Inflasi (X2) & -3.812302 & 0.0010 \\
Kurs (X3) & -0.016044 & 0.0000 \\
Dow Jones (X4) & 0.007039 & 0.0033 \\
C & 4.160576 & 0.8163 \\
AR (1) & 0.296683 & 0.1067 \\
AR (2) & -0.253417 & 0.2409 \\
R-squared & 0.73219 & \\
Prob (F-Stat) & 0.0000 & \\
Durbin-Watson stat & 1.986824 & \\
\hline
\end{tabular}

Sumber: Eviews 9, data diolah

QE Journal | Vol.06 - No. 01 Maret 2017 - 23 
Berdasarkan hasil metode Cochrane-Orcutt (C-O) maka diperoleh model regresi baru dengan memasukkan model $\mathrm{AR}(2)$ sebagai berikut.

Model dasar yang dipakai dalam Cochrane-Orcutt (C-O) yaitu:

$$
Y_{t}=\beta_{1}+\beta_{2} X_{t}+\varepsilon_{t}
$$

Berdasarkan hasil analisis regresi diatas diperoleh nilai dw sebesar 1.98, angka ini berada di antara $\mathrm{dU}$ dan $4-\mathrm{dU}$, atau $\mathrm{dU}<\mathrm{dw}<4-\mathrm{dU}$, sehingga dapat disimpulkan bahwa analisis regresi diatas bebas dari gejala autokorelasi. Adapun persamaan yang dipeoleh dari model AR(2) yaitu:

$$
\begin{aligned}
\mathrm{Y} & =1.61+15.6 \mathrm{X} 1-3.93 \mathrm{X} 2-0.01 \mathrm{X} 3+0.007 \mathrm{X} 4+[\mathrm{AR}(1) \\
& =0.29, \mathrm{AR}(2)=0.25, \mathrm{UNCOND}]
\end{aligned}
$$

Berdasarkan hasil estimasi diatas, maka hasil regresi Cochrane-Orcutt (C-O) dengan $\mathrm{AR}(2)$ dapat dipakai sebagai model regresi dalam penelitian ini.

\section{Uji Hipotesis}

Uji f digunakan untuk melihat apakah semua variabel bebas yang dimasukkan dalam model secara menyeluruh berpengaruh signifikan terhadap variabel terikat. Berdasarkan hasil regresi diperoleh nilai prob (Fstatistik) sebesar 0.0000, lebih kecil dari $\alpha=5 \%$, maka secara keseluruhan variabel bebas berpengaruh signifikan terhadap variabel terikat. Dengan demikian BI Rate, inflasi, kurs, dan indeks dow jones secara simultan berpengaruh signifikan terhadap return indeks Infobank15.

Tabel 7. Hasil Uji t

\begin{tabular}{lll}
\hline Variabel & Prob & keterangan \\
\hline BI Rate $(x 1)$ & 0.020 & Signifikan \\
Inflasi $(x 2)$ & 0.006 & Signifikan \\
Kurs $(x 3)$ & 0.000 & Signifikan \\
DJ $(x 4)$ & 0.013 & Signifikan \\
\hline
\end{tabular}

Sumber: Eviews 9, data diolah

Uji t merupakan uji statistik yang digunakan untuk menunjukkan apakah variabel bebas secara individu mempunyai pengaruh yang signifikan terhadap variabel terikat pada tingkat kepercayaan 95\%. Berdasarkan hasil analisis diatas variabel BI rate memililiki nilai probabilitas sebesar 0.02 , dimana nilai ini lebih kecil dari $\alpha=5 \%$. Hasil ini menunjukkan bahwa 
variabel BI Rate juga berpengaruh secara signifikan terhadap return indeks Infobank15. Lalu variabel Inflasi ( $\left.\mathrm{x}_{2}\right)$ memiliki nilai probabilitas sebesar 0.006, lebih kecil dari nilai dari $\alpha$ sebesar 5\%. Hasil ini memperlihatkan bahwa variabel inflasi berpengaruh signifikan terhadap return indeks Infobank15.Variabel kurs memiliki nilai probabilitas sebesar 0.0000 , lebih kecil dari $\alpha=5 \%$. Dengan demikian pengujian menunjukkan bahwa variabel kurs berpengaruh secara signifikan terhadap return indeks Infobank15. Variabel indeks dow jones memiliki nilai probabilitas sebesar 0.013 yang berarti nilai ini lebih kecil dari $\alpha=5 \%$ sehingga dapat dikatakan bahwa variabel indeks dow jones $\left(\mathrm{x}_{4}\right)$ berpengaruh signifikan terhadap return indeks Infobank15.

Uji koefisien determinasi (R-squared) dilakukan untuk melihat seberapa besar kemampuan variabel bebas $X$ dalam mempengaruhi variabel terikat Y. Berdasarkan hasil analisis regresi diperoleh nilai $R$-squared sebesar 0.73 , hal ini menandakan bahwa $73 \%$ variabel return saham perbankan dapat dijelaskan oleh variabel bebas Kurs, Inflasi, BI Rate, dan Indeks Dow Jones, sementara sisanya dijelaskan oleh variabel lain diluar persamaan model regresi.

Berdasarkan hasil analisis yang diperoleh, BI Rate secara signifikan berpengaruh positif terhadap return indeks saham perbankan dengan nilai koefisien sebesar 15.6, sehingga dapat dikatakan bahwa apabila tingkat BI Rate meningkat sebesar 1\% maka return indeks saham Infobank15 akan meningkat sebesar $15.6 \%$ dengan asumsi variabel bebas yang lain bersifat konstan, ceteris paribus. Hasil ini didukung oleh penelitian terdahulu yang dilakukan oleh Pasaribu dan Firdaus (2013) yang menunjukkan bahwa tingkat suku bunga BI Rate berpengaruh positif signifikan terhadap Indeks Saham Syariah Indonesia (ISSI). Kondisi ini disebabkan oleh hubungan perbankan dan pasar modal yang saling melengkapi dan perilaku investor dalam menilai masing-masing sektor memiliki karateristik tersendiri sehingga pasar modal dan perbankan dapat berjalan beriringan tanpa ada persaingan yang berarti.

Hubungan yang signifikan antara BI Rate dan return saham Indeks Infobank15 disebabkan selama periode pengamatan tingkat suku bunga Indonesia bergerak stabil dengan rata-rata tingkat suku bunga bulanan sebesar 7.08\%. Hal ini juga sejalan dengan penelitian yang dilakukan oleh Hussein dan Mgammal (2012). Hubungan positif ini menandakan tidak 
adanya hubungan substitusi antara sektor perbankan dengan pasar modal, melainkan sebagai komplementer dari perbankan. Argument ini diperkuat oleh Warjiyo (2004) yang menyatakan bahwa transmisi kebijakan moneter pada dasarnya menunjukkan interaksi antara bank sentral, perbankan, dan lembaga keuangan lain. Perbankan melakukan interaksi di pasar keuangan untuk portofolio investasinya baik untuk kepentingan sendiri maupun nasabahnya. Salah satu interaksi yang dilakukan yaitu di pasar modal, sehingga dengan adanya interaksi ini dapat menjadi pelengkap antara perbankan dengan pasar modal, sehingga suku bunga yang berlaku akan mempengaruhi kinerja saham.

Selain itu, hasil analisis ini berbeda dengan teori disebabkan emiten yang masuk kedalam indeks saham Infobank15 merupakan saham-saham yang tergolong bagus kinerjanya, dari rasio dan kinerja Good Corporate Governance(GCG). Emiten yang terdaftar dalam indeks ini tidak mudah terpengaruh oleh kondisi pasar. Seperti yang dijelaskan oleh Wira (2014), adanya emiten yang tetap bertahan meskipun suku bunga tinggi disebabkan oleh perusahaan tersebut menyasar ke segmen menengah ke atas. Segmen ini biasanya memiliki pendapatan yang lebih tinggi, selain itu perusahaan memiliki produk yang unik, merk yang kuat dan mempunyai kekuatan dominan di pasar, hal ini dapat dilihat melalui tingginya pangsa pasar sektor perbankan yang ada di pasar modal.

\section{Pengaruh Inflasi Terhadap Return Indeks Saham Perbankan Infobank15}

Berdasarkan hasil uji statistik diperoleh hubungan negative antara inflasi dengan return saham perbankan dengan nilai koefisien sebesar -3.93. hal ini berarti apabila laju inflasi meningkat sebanyak $1 \%$ maka terjadi penurunan return indeks saham perbankan Infobank15 sebesar $3.93 \%$ dengan asumsi variabel bebas yang lain konstan, ceteris paribus. Hasil ini sejalan dengan teori yang dikemukakan oleh Fama (1981) dalam penelitian yang dilakukan oleh Ioannidis dan Kontonikas (2013), yaitu return saham berhubungan negative dengan inflasi. Selain itu, penelitian ini juga sejalan dengan penelitian yang dilakukan oleh Emma dkk (2011), Rowland \& Mikail (2013), dan Dr Safdar (2014).

Berdasarkan teori, ketika suku bunga nominal meningkat maka inflasi akan meningkat karena suku bunga nominal merupakan formulasi jumlah dari suku bunga riil ditambah inflasi. Jadi, suku bunga nominal dan inflasi 
hubungannya searah. Akibat yang terjadi ketika inflasi meningkat maka harga saham akan turun sehingga berpengaruh negative terhadap return yang diperoleh nantinya, akibatnya tingkat investasi akan menurun, dan hal ini disebabkan adanya substitusi portofolio, yaitu pengalihan invetasi dari saham ke investasi yang bebas risiko seperti obligasi pemerintah dan Surat Berharga Bank Sentral. Pengalihan portofolio ini disebabkan imbal hasil yang diperoleh dari investasi bebas risiko lebih menarik, sehingga hal ini berakibat pada aksi jual dan minimnya permintaan akan saham.

Pengaruh Kurs Terhadap Return Indeks Saham Perbankan Infobank15

Berdasarkan hasil uji statistik diperoleh kurs berpengaruh negative terhadap return saham dengan nilai koefisien -0.016. Ketika kurs meningkat sebanyak 1 satuan maka return saham Infobank15 akan menurun sebanyak $0.016 \%$ dengan asumsi variabel bebas yang lain konstan, ceteris paribus. Hasil ini menunjukkan bahwa ketika nilai tukar turun, maka investor asing kurang berminat untuk berinvestasi di pasar modal domestic karena ketika mata uang domestic dikonversikan ke mata uang negaranya, ia merasa rugi sehingga hal ini memicu adanya capital outflow yang berakibat pada penurunan return saham.

Secara empiris, Hasil ini tidak sejalan dengan penelitian sebelumnya yang dilakukan Mahfoudh dan Mgammal (2012), dan Dr Afdar (2014). Namun disisi lain hasil ini sejalan dengan penelitian yang dilakukan oleh Zohain Khan dkk (2012) yang menyatakan bahwa kurs berpengaruh negative dan signifikan terhadap return saham. Hasil yang sama juga diperoleh melalui penelitian yang dilakukan oleh Syed dan Anwar (2012). Adanya pelemahan nilai tukar domestic dapat mengakibatkan kerugian pada pasar modal dalam negeri, dimana penurunan nilai tukar akan menyebabkan pasar saham kurang diminati.

Pengaruh Indeks Dow Jones terhadap Return Indeks Saham Perbankan Infobank15

Berdasarkan hasil uji statistik diperoleh hubungan yang positif dan signifikan antara indeks asing Dow Jones dengan return saham indeks perbankan. Hasil ini dapat dilihat dari nilai koefisien sebesar 0.007 . berdasarkan hasil ini ketika indeks Dow Jones meningkat sebanyak satu satuan maka return saham indeks Infobank15 akan meningkat sebesar 
$0.007 \%$ dengan asumsi variabel bebas yang lain bersifat konstan, ceteris paribus.

Pernyataan ini sejalan dengan pernyataan Achsani (2000). Dikatakan bahwa dalam kasus Dow Jones, saham-saham yang listing di luar negeri akan terkena dampaknya. Dengan jatuhnya Dow Jones harga saham kita yang ada diluar negeri akan jatuh, akibatnya harga saham yang ada di BEI juga akan terkena dampak yang sama. Selain itu, Nezky (2013) juga menyatakan bahwa keadaan krisis di Amerika Serikat turut berpengaruh signifikan terhadap pasar modal Indonesia, hal ini dibuktikan melalui pergerakan Indeks Dow Jones yang memberikan respon searah dengan keadaan IHSG sehingga dapat dikatakan bahwa pasar modal di Indonesia masih dipengaruhi oleh pasar modal asing, jika terjadi shock pada indeks saham besar luar negeri maka investor domestic juga akan terkena dampaknya.

Bursa saham internasional saling mempengaruhi satu sama lain. Salah satu yang cukup berpengaruh adalah bursa asing Dow Jones. Fenomena interaksi ini terjadi karena adanya dominasi ekonomi Amerika sehingga secara otomatis akan mempengaruhi ekonomi global, adanya kemajuan teknologi komunikasi sehingga informasi dapat diperoleh secara cepat dan pelaku pasar dapat mengantisipasi setiap perubahan peristiwa yang ada, dan tidak jarang pula satu perusahaan melakukan listing di beberapa pasar saham sehingga apabila terjadi perubahan harga saham maka harga saham di bursa lainnya juga terpengaruh.

\section{SIMPULAN DAN SARAN}

\section{Simpulan}

Berdasarkan hasil penelitian dan pembahasan yang telah dilakukan, maka dapat ditarik kesimpulan. Pertama, kebijakan moneter secara signifikan berpengaruh terhadap return indeks saham Infobank15. BI Rate berpengaruh positif terhadap return saham Infobank15, dimana ketika BI rate naik maka return saham perbankan akan ikut naik. Meskipun tidak sesuai dengan teori dapat dijelaskan bahwa emiten-emiten yang terdaftar dalam Indeks Infobank15 merupakan emiten yang dianggap bagus kinerjanya, selain itu adanya kinerja yang inovatif dan pangsa pasar yang tinggi juga mempengaruhi return sahamnya. Kedua, inflasi dan kurs berpengaruh negative terhadap return indeks Infobank15, dimana ketika

QE Journal | Vol.06 - No. 01 Maret 2017 - 28 
inflasi dan kurs meningkat maka return indeks Infobank15 akan menurun. Ketiga, bursa asing Dow Jones berpengaruh positif signifikan terhadap return indeks saham Infobank15, namun kurang dominan karena indeks saham di Indonesia lebih dipengaruhi oleh indeks saham regional, seperti indeks saham Singapura. Bursa asing Dow Jones menunjukkan hubungan positif dengan return indeks Infobank15. Keempat, berdasarkan uji statistik, seluruh variabel bebas berpengaruh signifikan terhadap return indeks saham perbankan. Hal ini mengindikasikan bahwa variabel kebijakan moneter dan indeks bursa asing merupakan indikator yang digunakan oleh investor untuk berinvestasi di pasar modal, khususnya sektor perbankan.

\section{Saran}

Berdasarkan kesimpulan dari penelitian yang diperoleh, maka ada beberapa saran yang disajikan sebagai berikut. Pertama, dalam berinvestasi, selain melihat kondisi internaI perusahaan emiten, investor sebaiknya juga lebih teliti dalam menganalisis bagaimana keadaan perekonomian, khususnya perkembangan kebijakan moneter sebelum berinvestasi, sehingga dengan demikian dapat memaksimalkan return yang akan mereka peroleh nantinya. Kedua, dalam menjalankan aktivitas transmisinya, Bank Indonesia selaku Otoritas Moneter sebaiknya lebih memperhatikan perkembangan suku bunga BI Rate sebagai suku bunga acuan dan memperhatikan informasi pasar yang ada di lantai bursa, karena berdasarkan hasil penelitian diperoleh BI Rate berpengaruh dominan terhadap return saham perbankan. Selain itu Bank Indonesia perlu melakukan evaluasi dan peningkatan komunikasi dalam formulasi dan implementasi kebijakan moneter yang akan diterapkan. Ketiga, untuk lebih menyempurnakan model analisis terkait return saham perbankan diperlukan penelitian lebih lanjut terkait topik ini. Hal ini dikarenakan masih terbatasnya penelitian terdahulu, khususnya di Indonesia. Selain itu, karena indeks saham Infobank15 merupakan indeks saham perbankan yang baru diluncurkan oleh Bursa Efek Indonesia maka dibutuhkan penelitian yang lebih lanjut mengenai indeks ini, misalnya dengan menambah variabel penelitan sehingga dapat mewakili kondisi ekonomi secara keseluruhan. 


\section{DAFTAR PUSTAKA}

Achsani, Noer Azzam. 2000. Mencermati Kejatuhan Indeks Dow Jones: Akankah Indeks BEJ Ikut Terseret?. University of Postdam. Postdam.

Bank Indonesia. 2016. Kalkulator Kurs. www.bi.go.id. Diakses pada 20 April 2016.

Bank Indonesia. 2016. Laporan Inflasi ( Indeks Harga Konsumen). www.bi.go.id. Diakses pada 20 April 2016.

Bernanke, B. S., \& Kuttner, K. N. 2005. What Explains the Stock Market's Reaction to Federal Reserve Policy? The Journal Of Finance, 60(3), 1221-1257.

Bernanke, B., \& Gertler, M. 1989. Agency Costs, Net Worth, and Business Fluctuations. The American Economic Review, 14-31.

Dornbusch, R., \& Fischer, S. 1980. Exchange Rates and The Current Account. The American Economic Review, 960-971.

Ehrmann, M., \& Fratzscher, M. 2004. Taking Stock: Monetary Policy Transmission to Equity Markets. Working Paper Series, 1-48.

Güray , K., Ünalmiş, D., \& Ünalmiş, İ. 2013. How Do Banks' Stock Returns Response to Monetary Policy Committee Announcements in Turkey? Evidence from Tradisional Versus New Monetary Policy Episodes. Working Paper No: 13/30, 1-26.

Hussein, M., \& Mgammal, H. 2012. The Effect of Inflation, Interest Rates and Exchange Rates on Stock Prices Comparative Study Among Two Gcc Countries. International Journal of Finance and Accounting2012, 1(6), 179-189.

Iglesias, E. M., \& Haughton, A. Y. 2011. Interaction Between Monetary Policy and Stock Prices: A Comparison Between the Carribean and the US. Applied Financial Economics, 1-50.

Ioannidis, C., \& Kontonikas, A. 2008. The Impact of Monetary Policy on Stock Prices. Journal of Policy Modeling, 30, 33-53.

QE Journal | Vol.06 - No. 01 Maret 2017 - 30 
Khan, Z., Khan, S., Rukh, L., \& Imdadullah. 2012. Impact of Interest Rate, Exchange Rate and Inflation on Stock Returns of KSE 100 Index. International Journal of Economics and Research-IJER , 142-155.

Nezky, M. 2013. Pengaruh Krisis Ekonomi Amerika Serikat Terhadap Bursa Saham dan Perdagangan Indonesia. Buletin Ekonomi Moneter dan Perbankan, pp. 89-104.

Prastowo, N. J. 2008. Dampak BI Rate Terhadap Pasar Keuangan : Mengukur Signifikasi Respon Instrumen Keuangan Terhadap Kebijakan Moneter. WP/21/2007, 1-61.

Purnamawati, I. G., \& Werastuti, D. N. 2013. Faktor Fundamental Ekonomi Makro Terhadap Harga Saham LQ45. Jurnal Keuangan dan Perbankan, vol.17, 2011-219.

Puspopranoto, S. 2004. Keuangan Perbankan dan Pasar Keuangan : Konsep, Teori, dan Realita. Jakarta: LP3ES.

Tobin, J. 1969. A General Equilibrium Approach To Monetary Policy. Journal of Money, Credit and Banking, 1(1), 15-29.

Warjiyo, P. 2004. Mekanisme Transmisi Kebiijakan Moneter di Indonesia. Seri Kebanksentralan No. 11, pp. 1-56.

Yahoo Finance. 2016. DJI Historical Prices. www.finance.yahoo.com. Diakses pada 20 April 2016. 